ALFONSO REYES AND SPAIN 


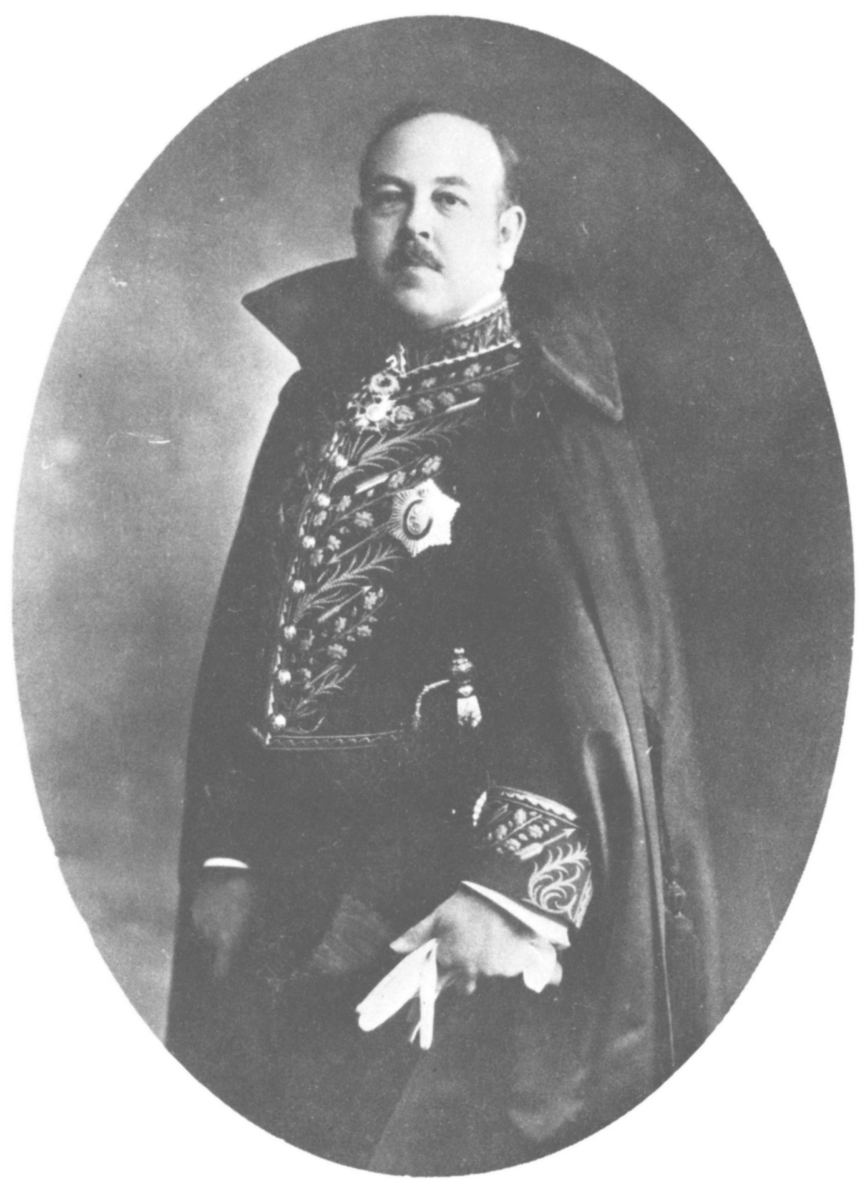

A L F O N S O R E Y E S

Madrid, 1923 


\section{Alfonso Reyes and Spain}

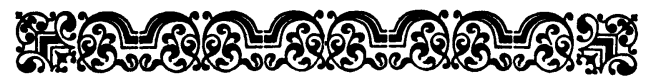

HIS DIALOGUE WITH

Unamuno, Valle-Inclán,

Ortega y Gasset, Jiménez, and

Gómez de la Serna

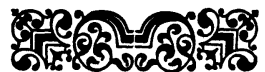

BY BARBARA BOCKUS APONTE 
International Standard Book Number 0-292-70300-7

Library of Congress Catalog Card Number 78-37254

(C) 1972 by Barbara Bockus Aponte

All rights reserved

Type set by G\&S Typesetters, Austin

Printed by The University of Texas Printing Division, Austin

Bound by Universal Bookbindery, Inc., San Antonio

ISBN 978-0-292-73338-1 (library e-book)

ISBN 978-0-292-73339-8 (individual e-book) 
To my father 
THIS PAGE INTENTIONALLY LEFT BLANK 